\title{
KIOBEL AND THE NEW BATTLE OVER CONGRESSIONAL INTENT
}

\author{
By David H. Moore*
}

Transnational human rights litigation under the Alien Tort Statute (ATS $)^{1}$ has been plagued by the overarching question of the domestic legal status of customary international law (CIL). ${ }^{2}$ Kiobel v. Royal Dutch Petroleum $\mathrm{Co}^{3}$ is the Supreme Court's second installment on the ATS. Like Sosa v. Alvarez-Machain ${ }^{4}$ before it, Kiobel does not expressly address the domestic legal status of CIL, but it does provide clues. Those clues suggest two insights: the Court views CIL as external to U.S. law, rather than as part of federal common law, and the role of CIL in future cases may be affected less by arguments about CIL's status as federal common law than by arguments about congressional intent.

\section{The Domestic Legal Status of Customary International Law}

As is well known, the debate over the domestic status of CIL has produced two principal camps. Adherents of the modern position, with support from the Restatement (Third) of the Foreign Relations Law of the United States, maintain that CIL is a type of federal common law. As a result, it may be applied by federal courts on their own initiative. By contrast, adherents of the revisionist position maintain that federal courts may apply CIL as federal law only when authorized to do so by federal statute or the federal Constitution. In their view, CIL is not domestic law until positively incorporated.

Both sides claimed at least partial victory after Sosa. ${ }^{5}$ On the one hand, some modernists found support in the view that the Court "characterized customary international law as 'federal

* Professor of Law, Brigham Young University, J. Reuben Clark Law School.

${ }^{1} 28$ U.S.C. $\$ 1350$.

${ }^{2}$ I say "plagued" because this question has often obscured the injustice alleged in the litigation. ATS cases have involved troubling allegations of human rights abuses, such as genocide, torture, slavery, murder, and rape. In addition, the question has received extensive attention from scholars, including myself. Although the attention may have at times been inordinate, the question remains important, not least because of its significance for the vertical and horizontal distribution of governmental power.

${ }^{3}$ Kiobel v. Royal Dutch Petroleum Co., 133 S.Ct. 1659 (2013).

${ }^{4}$ Sosa v. Alvarez-Machain, 542 U.S. 692 (2004).

${ }^{5}$ For claims that Sosa supports the revisionist position, see Curtis A. Bradley, Jack L. Goldsmith \& David H. Moore, Sosa, Customary International Law, and the Continuing Relevance of Erie, 120 HARV. L. REV. 869, 873, 902-10 (2007) ("[T] he decision in Sosa cannot reasonably be read as embracing the modern position and, indeed, is best read as rejecting it."); and David H. Moore, An Emerging Uniformity for International Law, 75 GEO. WASH. L. REV. 1, 8, 48-49 (2006) ("Far from endorsing the [modern] view of CIL, the Court nodded support for the [revisionist] position by demonstrating that the application of CIL in federal courts turns on congressional intent."). For claims that Sosa supports the modern position, see Harlan Grant Cohen, Supremacy and Diplomacy: The International Law of the U.S. Supreme Court, 24 BERKELEY J. INT'L L. 273, 285 (2006) ('Justice Souter['s opinion in Sosa] resolves the debate. Customary international law is federal common law."); Leila Nadya Sadat, An American Vision for Global Justice: Taking the Rule of (International) Law Seriously, 4 WASH. U. GLOBAL STUD. L. REV. 329, 342 (2005) (claiming that "a six-member majority of the Supreme Court rejected [the revisionist] view in Sosa v. Alvarez-Machain"); Martin S. Flaherty, The Future and Past of U.S. Foreign Relations Law, 67 LAW \& CONTEMP. PROBS., Fall 2004, at 169, 173 (arguing that Sosa "confirm[s] that international custom was part of judicially enforceable federal law even in the absence of a statute"); Harold Hongju Koh, The 2004 Term: The Supreme Court Meets International Law, 12 TULSA J. COMP. \& INT'L L. 1, 12 (2004) (asserting that Sosa rejected the revisionist position); and Ralph G. Steinhardt, Laying One Bankrupt Critique to Rest: Sosa v. Alvarez-Machain and the Future of International Human Rights Litigation in U.S. Courts, 57 VAND. L. REV. 2241, 2255 (2004) (asserting that "the Supreme Court [in Sosa] explicitly reaffirmed the orthodox legitimacy of international law as law of the United 
common law' for purposes of the Alien Tort Statute." Revisionists, on the other hand, noted the Court's reliance on congressional intent and the Court's emphasis on both the judiciary's limited role and the narrowness of federal common law after Erie Railroad Co. v. Tompkins. ${ }^{7}$

The Court's more recent opinion in Kiobel tends to undermine the modern position and support the revisionist position. To the extent that Sosa provided support for the modern position by finding a common law role for CIL under the ATS, Kiobel clearly erodes that support. Sosa itself authorized the creation of common law claims only as to CIL norms that are as specifically defined and well accepted as the norms that Congress had in mind in enacting the ATS. Kiobelwent much further in reducing the CIL-based claims that remain plausible. After Kiobel, an ATS suit may not assert "violations of the law of nations occurring outside the United States" unless those violations "touch and concern the territory of the United States . . with sufficient force to displace the presumption against extraterritorial application" of common law causes of action based on CIL. ${ }^{8}$ It will take time to flesh out what it means to "touch and concern the territory of the United States ... with sufficient force," but there is no question that a range of CIL-based common-law claims that were viable post-Sosa are not post-Kiobel.

Moreover, in defining the scope of viable claims, the Kiobel Court followed Sosa's lead in turning to congressional intent. Under Sosa, the judiciary's lingering authority to create causes of action based on CIL was both grounded in and restricted by the intent of the First Congress in enacting the ATS. In Kiobel, the territorial reach of ATS causes of action is likewise discerned by reference to congressional intent, albeit after application of the presumption against extraterritoriality. ${ }^{9}$ One might expect that if CIL were federal common law and the judiciary were empowered under the ATS to create U.S. causes of action based on substantive CIL norms, then the judiciary would correspondingly invoke the CIL and federal common law of prescriptive jurisdiction as at least one source in deciding extraterritorial reach (as Justice Stephen Breyer did). ${ }^{10}$ Yet the Kiobel Court cut a path to congressional intent without any clear reference to CIL principles of prescriptive jurisdiction. ${ }^{11}$

Even as it emphasized congressional primacy, Kiobel, like Sosa, stressed the limited role of the judiciary in foreign affairs. ${ }^{12}$ In Kiobel, this emphasis is both express and implicit in at least two features of the Court's opinion: (1) the Court's assessment of the purpose of the ATS, and (2) the Court's chosen justification for the presumption against extraterritoriality. On the first

States ... [and] repudiate[d] the revisionist view according to which ATS human rights actions were intrinsically illegitimate").

${ }^{6}$ William S. Dodge, Bridging Erie: Customary International Law in the U.S. Legal System After Sosa v. AlvarezMachain, 12 TULSA J. COMP. \& INT'L. L. 87, 88 (2004) (footnote omitted); see also id. at 95-96; Derek Jinks \& David Sloss, Is the President Bound by the Geneva Conventions?, 90 CORNELL L. REV. 97, 104 n.27 (2004) (briefly asserting that Sosa "settled part of [the] debate, recognizing that some CIL is federal common law").

${ }^{7}$ Erie R.R. Co. v. Tompkins, 304 U.S. 64 (1938); see, e.g., Bradley, Goldsmith \& Moore, supra note 5, at 90206.

${ }^{8}$ Kiobel, 133 S.Ct. at 1669.

${ }^{9}$ See id. at 1665-69 (finding no compelling evidence in the text or history of the ATS that Congress intended ATS "causes of action to reach conduct in the territory of a foreign sovereign").

${ }^{10}$ See id. at 1670-74 (Breyer, J., concurring) (interpreting the ATS by reference to CIL prescriptive jurisdiction principles, not the presumption against extraterritoriality).

${ }^{11}$ See, e.g., id. at 1665-69 (majority opinion). Even though the Court did not rely on the CIL of prescriptive jurisdiction in limiting the reach of causes of action under the ATS, the Court might be motivated by the Constitution's federalist principles to impose CIL-inspired-or more aggressive-limits on state causes of action addressing extraterritorial CIL violations.

12 See id. at $1664-65$. 
score, the Court found that the First Congress turned to CIL not out of a general desire to improve CIL's enforcement but for instrumental reasons: to avoid foreign relations problems caused by CIL violations on U.S. soil that the federal government was helpless to remedy. ${ }^{13}$ If the First Congress's approach reflects the founding intent or understanding more generally, then CIL's relation to the federal judiciary might wax and wane depending on whether Congress determines that domestic incorporation serves U.S. interests.

As to the justification for the presumption against extraterritoriality, the Court had many options. Years ago, William Dodge summarized six possible justifications for the presumption, including securing compliance with CIL limits on extraterritoriality, effectuating the assumption that "Congress generally legislates with domestic concerns in mind," and avoiding foreign affairs problems resulting from unintended conflicts with other sovereigns' laws. ${ }^{14}$ In 2010 , in Morrison v. National Australia Bank, the Court grounded the presumption "on the perception that Congress ordinarily legislates with respect to domestic, not foreign matters," and explained that the presumption applies "regardless of whether there is a risk of conflict between the American statute and a foreign law." ${ }^{15}$ In Kiobel, the Court emphasized that the purpose behind the presumption is to avoid judicial triggering of conflicts with other states' laws that would generate foreign affairs problems that the political branches did not elect to incur. ${ }^{16}$ This justification comports with revisionist limitations on judicial power. It departs from the modern position's focus on international law enforcement in U.S. courts, a focus more consistent with a view that the presumption against extraterritoriality is meant to respect CIL limits on prescriptive jurisdiction.

Ultimately, the Court seemed to perceive CIL as existing in two spheres — one international and one domestic - with the scope of the domestic departing from the international according to congressional intent. Consistent with this view (albeit not exclusively so), the Court indicated that, when federal courts consider ATS claims, "[ $\mathrm{t}]$ he question is ... whether the court has authority to recognize a cause of action under U.S. law to enforce a norm of international law."17

Of course, this quotation and other aspects of the opinion might be explained by arguing that Kiobel is relevant only to the scope of U.S. causes of action based on CIL and not to the domestic status of CIL more generally. The same could be said of Sosa. As to Sosa, Jack Goldsmith, Curtis Bradley and I have observed that much of Sosa's discussion of Erie "would have been largely unnecessary if the Court had been simply speaking to the circumstances under

${ }^{13}$ See, e.g., id. at $1666-68$.

${ }^{14}$ William S. Dodge, Understanding the Presumption Against Extraterritoriality, 16 BERKELEY J. INT'L L. 85, 90 (1998).

${ }^{15}$ See Morrison v. Nat'l Austl. Bank Ltd., 130 S.Ct. 2869, 2877-78 (2010). But cf. id. at 2885-86 (refusing to apply the Securities Exchange Act to certain domestic conduct causing foreign effects, given the risk of conflict with other states' laws that Congress "'would have addressed" " had it "intended such foreign application" (quoting EEOC v. Arabian Am. Oil Co., 499 U.S. 244, 256 (1991))).

${ }^{16}$ Kiobel, 133 S.Ct. at $1664-65,1669$. The Court also briefly alluded to a related justification for the presumption- "separation-of-powers concerns" that the judiciary lacks the authority and competence to calibrate the extraterritorial reach of federal statutes. Dodge, supra note 14, at 90; see Kiobel, 133 S.Ct. at 1664 (noting that Congress "alone has the facilities necessary to make fairly ... [the] important policy decision [of extraterritorial reach] where the possibilities of international discord are so evident and retaliative action so certain" (quoting Benz v. Compania Naviera Hidalgo, S.A., 353 U.S. 138, 147 (1957))).

${ }^{17}$ Kiobel, 133 S.Ct. at 1666 (emphases added); see also id. at 1664 (The ATS "allows federal courts to recognize certain causes of action based on sufficiently definite norms of international law."). 
which courts may imply a cause of action from existing domestic law, an issue generally governed by different precedent," that "the Court referred to limits on implied rights of action as only one of many reasons for judicial caution in allowing claims under the ATS," and that "the Court's view of post-Erie federal common law is inconsistent with the proposition that CIL automatically and in a wholesale fashion has the status of federal law, even outside the context of causes of action." 18 Similarly, there is some reason to believe that Kiobel bears not just on the scope of CIL-based causes of action but on the broader domestic status of CIL. On this score, perhaps the most relevant feature of the Kiobel opinion is the Court's application of the presumption against extraterritoriality to the CIL-based cause of action and not to the CIL prohibition on primary behavior. ${ }^{19}$ In Morrison, the immediate antecedent to Kiobel in terms of the presumption against extraterritoriality, the Court applied the presumption to both the cause of action and the federal statute from which it was implied. ${ }^{20}$ The Kiobel Court may have applied the presumption only to the cause of action because it was not created by, or was more limited than, the substantive norm of CIL. Yet the Court may have understood that only the cause of action, not the CIL prohibition, was U.S. law.

\section{The Battle for Congressional Intent}

Though far from definitive, these insights suggest that Kiobel tends toward the revisionist position on the domestic status of CIL. I have previously argued that, in light of Sosa's support for the revisionist view, the battle over the domestic role of CIL should shift from the courts to Congress. ${ }^{21}$ Kiobel strengthens that argument. At the same time, Sosa and Kiobel together suggest an intermediate battleground: the battle for congressional intent in the judiciary. How a court perceives congressional intent will have a significant impact on whether its holding resembles the modern or revisionist position. Sosa and Kiobel indicate that the goals of the modern position may be accomplished within the revisionist framework. The path to that end lies through congressional intent. Both opinions demonstrate that congressional intent can be understood in ways that are more or less receptive to CIL and that provide more or less room for the judiciary to incorporate CIL.

To illustrate, compare the treatment of congressional intent in Sosa and Kiobel. In Sosa, the Court spent considerable time seeking to understand the intent of the First Congress in enacting the ATS. The Court concluded that, through the ATS, the First Congress granted federal courts jurisdiction "on the understanding that the [general] common law would provide a cause of action for the modest number of international law violations with a potential for personal liability at the time." ${ }^{22}$ General common law did not support federal jurisdiction or preempt state law. ${ }^{23}$ Under the banner of congressional intent, the Court then translated the First Congress's understanding into a post-Erie world in which federal common law can support

${ }^{18}$ See Bradley, Goldsmith \& Moore, supra note 5, at 909.

${ }^{19}$ See Kiobel, 133 S.Ct. at 1664 (noting that "[w] typically apply the presumption to discern whether an Act of Congress regulating conduct applies abroad").

20 See Morrison, 130 S.Ct. at 2875, 2881 n. 5, 2883.

${ }^{21}$ See, e.g., Moore, supra note 5, at 52.

${ }^{22}$ Sosa v. Alvarez-Machain, 542 U.S. 692, 724 (2004).

23 See Bradley, Goldsmith \& Moore, supra note 5, at 874-75. 
federal subject matter jurisdiction and preempt state law. ${ }^{24}$ The result was that a pre-Erie intent to engage a general common law that could not support federal jurisdiction or preempt state law produced a post-Erie common law that could. Through the medium of congressional intent, the judiciary exercised significant leeway to create a much more robust law based on CIL than the First Congress would have anticipated.

By contrast, Kiobel discerned congressional intent in a way that severely restricts judicial resort to CIL under the ATS. Kiobel applied the presumption against extraterritoriality to common law causes of action based on CIL, although the presumption's normal target is statutory proscriptions. ${ }^{25}$ The Court then found the presumption controlling, notwithstanding the ATS's attempt to reach piracy and its references to aliens, the law of nations, and treaties. ${ }^{26}$ As in Sosa, the Court's reasoning is not indefensible, but it illustrates a more restrictive approach to congressional intent and hence to judicial resort to CIL.

To be sure, the battle over congressional intent is not entirely new. Modernists and revisionists, for example, have long debated the significance of congressional enactment of the Torture Victim Protection $\mathrm{Act}^{27}$ for the future of ATS litigation. ${ }^{28}$ Yet, given Sosa's and Kiobel's focus on congressional intent and consistency with the revisionist position, the battle over congressional intent has gained a new prominence. Going forward, advocates should focus much less on how much congressional intent matters and much more on what that intent means. 